\title{
Role of Angiogenesis and Microenvironment in Melanoma Progression
}

\author{
Roberto Ria, Antonia Reale and Angelo Vacca \\ University of Bari \\ Italy
}

\section{Introduction}

The growth, survival and proliferation of cancer cells are guaranteed by a crosstalk between cancer cells themselves and surrounding host cells and extracellular matrix. An intense area of research has contributed to a better understanding of the pathophysiological modification of tumour progression, e.g., the role of microenvironment.

Human malignant melanoma is a highly metastatic tumour with poor prognosis and extreme resistance to treatment. It progresses through different steps: nevocellular nevi, dysplastic nevi (when these two entity can be identified as primary events in melanocytic neoplasia progression), in situ melanoma, radial growth phase melanoma (Breslow index $\leq 0.75 \mathrm{~mm}$ ), vertical growth phase melanoma (index $>0.75 \mathrm{~mm}$ ), and metastatic melanoma (Breslow, 1970). Primary tumour grows horizontally through the epidermis; over time, a vertical growth phase component intervenes and melanoma increases its thickness and invades the dermis. Once a vertical growth phase has developed, there is a direct correlation between the tumour thickness and the number of metastases (Heasley et al., 1996).

Parallel with progression, melanoma acquires a rich vascular network. Melanoma neovascularization has been correlated with poor prognosis, shorter overall survival, ulceration and increased rate of relapse (Srivastava et al., 1988, 1989). This neovascularization is initiated and maintained by mean the secretion of various angiogenic cytokines, i.e. Vascular Endothelial Growth Factor-A (VEGF-A), Fibroblast Growth Factor-2 (FGF-2), Placental Growth Factor (PGF) -1 and -2, Interleukin (IL) -8, Transforming Growth Factor-1 (TGF-1), by melanoma cells. Moreover cytokines production has been correlated to the transition from the radial to the vertical growth phase, and to the metastatic phase (Erhard et al., 1997; Marcoval et al., 1997; Salven et al., 1997).

\section{Human melanoma}

Human malignant melanoma originates from the melanocytes and manifests mainly on the skin. Rarely, melanomas can occur on the eye, the meninges, and the mucosa in different locations. The incidence of melanoma in white populations worldwide is increasing, especially in light skinned people with sun exposure. Melanomas are rare in populations with pigmented skin and almost always located on the mucosa or the palms of the hands or soles of the feet (Garbe et al., 2008). 
The most important etiological factor for the development of a melanoma is UV radiation. Even in childhood, the influence of UV radiation results in the development of benign melanocytic neoplasms, in the form of melanocytic nevi. These are indicators of acquired mutations in the melanocytic system. The more melanocytic nevi someone has, the higher their risk of developing melanoma. Melanomas develop primarily in sites with the highest numbers of melanocytic nevi (Garbe et al., 2008).

Clinically and histologically, four different subtypes of melanoma can be distinguished, which have different patterns of mutation: superficially spreading melanoma; nodular melanoma; lentigo maligna melanoma; acral lentiginous melanoma. The criteria of the $\mathrm{ABCDE}$ rule are the main diagnostic criteria (Asymmetry; Border irregularity; Color; Diameter; Evolving). Staging (American Joint Committee on Cancer Staging System) is important for selecting the best therapeutic approach (Balch et al., 2001, 2009).

\section{Tumour angiogenesis}

Angiogenesis is the sprouting of new blood vessels from a pre-existing vasculature and it is a tightly regulated process (Stasi \& Amadori, 2002). During embryogenesis two major processes of blood vessel formation are implicated in the development of the vascular system: vasculogenesis and angiogenesis (Risau, 1988).

Vasculogenesis starts from mesodermal-derived cells, the hemangioblasts, which differentiate both into angioblasts-endothelial cells and into hematopoietic stem cells. Vasculogenesis prevails in the embryo but it may have physiological roles in health and disease in adults (Iruela-Arispe \& Dvorak, 1997). Both mechanisms, angiogenesis and vasculogenesis, occur in ischemic and tumour tissues in response to growth factors, such as VEGF and FGF-2, produced by tumour and stromal cells (Folkman et al., 2001). In some aggressive tumours the vessel wall is lined with only cancer cells as a mosaic of cancer cells and endothelial cells. This phenomenon is called "vasculogenesis mimicry" (Dome et al., 2007).

Angiogenesis is uncontrolled and unlimited in time, and essential for tumour growth, invasion and metastasis during the transition from the avascular to the vascular phase, the so-called angiogenic switch, in which the balance between angiogenesis inducers and inhibitors leans towards the former. The vascular phase is characterized by the new formation of vascular channels that enhance tumour cell proliferation, local invasion, and hematogenous metastasis.

\subsection{Angiogenesis and human melanoma}

New blood vessel formation is a prominent feature of human melanomas, indicating that these tumours have angiogenic activity (Mihm et al., 1975). The observation that cutaneous melanoma cells acquire the capacity to actively induce the growth of new blood vessels dates back to the earliest days of tumour angiogenesis research, when Warren and Shubik observed it after transplantation of human melanoma fragments into a hamster cheek pouch (Warren \& Shubik, 1966). These studies were confirmed in later studies (Hubler \& Wolf, 1976). Rapid angiogenesis of cutaneous melanomas dramatically enhances the risk of lethality and contributes to the progression of the most common type of young adults (Streit \& Detmar, 2003). 


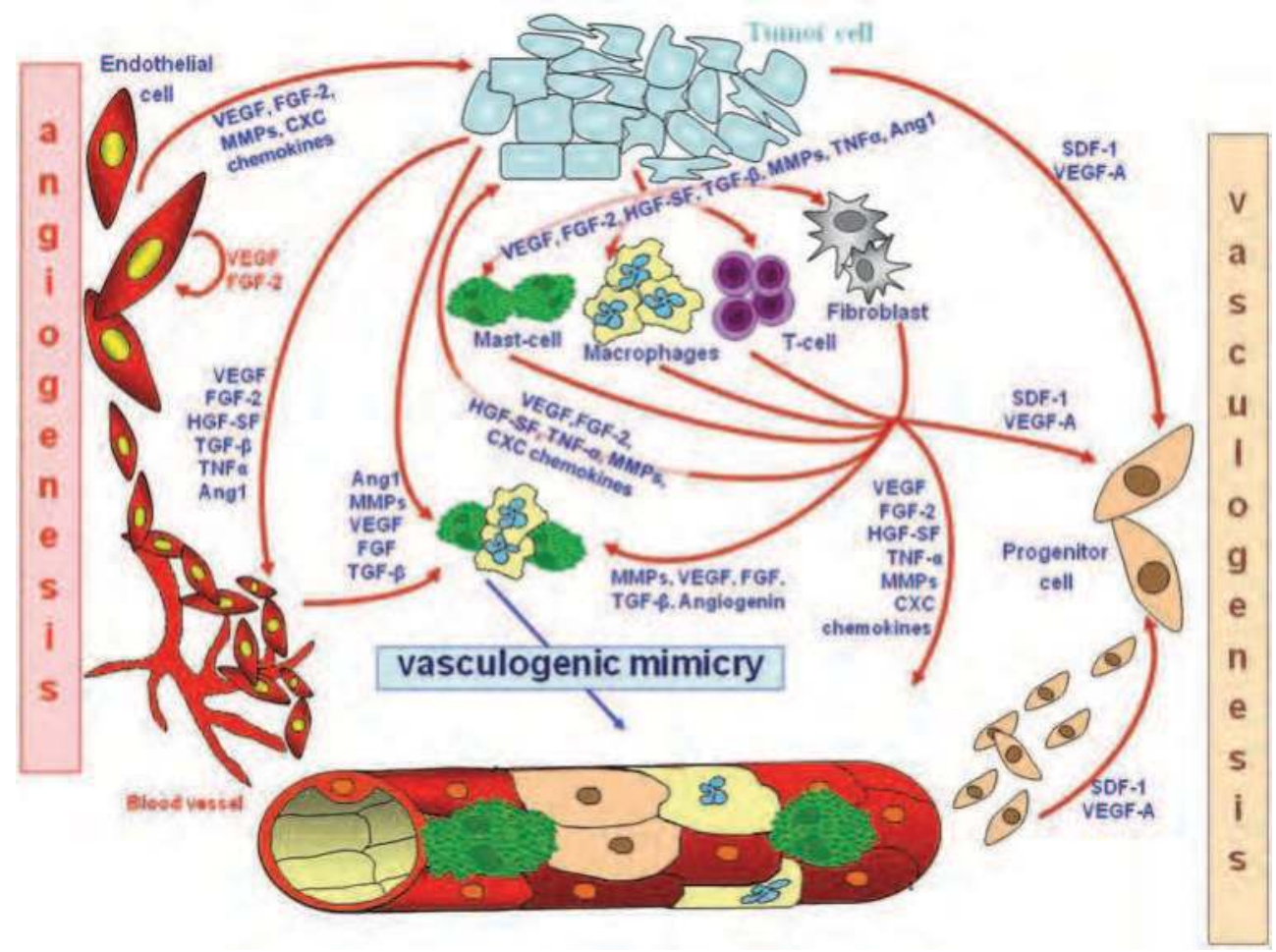

Fig. 1. Processes implied in neovessel formation tumor-induced

\subsubsection{The role of angiogenic cytokines}

Tumour angiogenesis depends mainly on the release by neoplastic cells of growth factors specific for endothelial cells, able to stimulate the growth of the host's blood vessels.

VEGF is expressed in most solid tumours and the VEGF receptors (VEGF-Rs) are predominant in endothelial cells surrounding or penetrating malignant tissue, but are absent from vascular cells in the surrounding normal tissue. This finding suggests that VEGF-Rs expression is induced in endothelial cells during tumour angiogenesis by VEGF secreted by tumour cells.

Secretion of VEGF-A isoform by melanoma cells has been correlated to the transition from the radial to the vertical growth phase, and to the metastatic phase (Erhard et al., 1997; Marcoval et al., 1997; Salven et al., 1997). Our previous studies indicated that increased microvascular density, strong VEGF-A tumour immunoreactivity, increased vascular diameter, and high number of vascular pillars-expression of the intussusceptive microvascular growth - are correlated to a high Breslow index $(>3.6 \mathrm{~mm})$. 

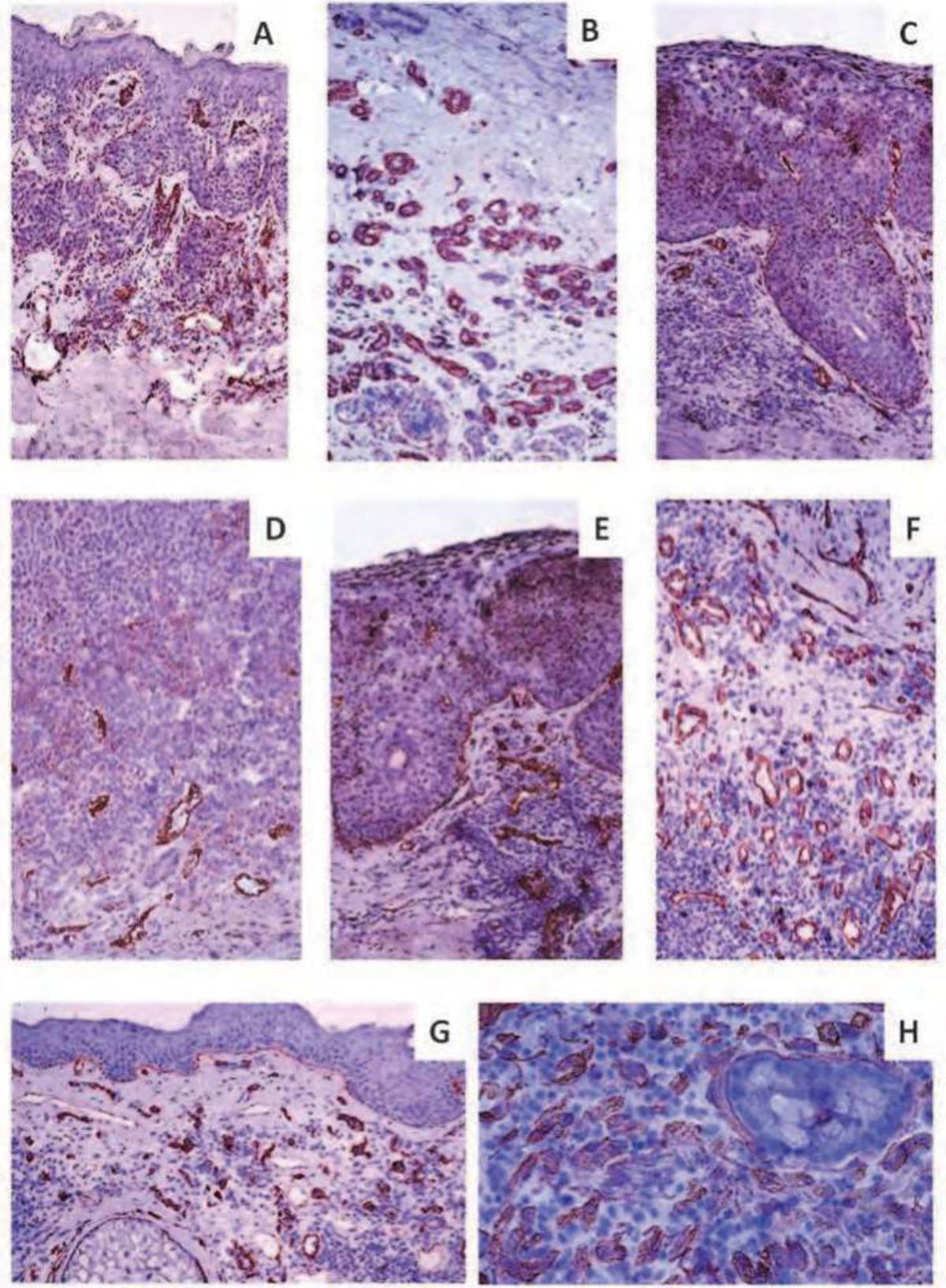

Fig. 2. Angiogenesis extent parallel with melanoma progression: A) common nevi, B) displastic nevi, C) microvessels under the base of melanoma, D) melanoma breslow 0.45 $\mathrm{mm}$, E) melanoma breslow $1 \mathrm{~mm}, \mathrm{~F}$ ) melanoma breslow $>3 \mathrm{~mm}, \mathrm{G}$ ) advanced melanoma with inflammatory infiltrate, $\mathrm{H}$ ) bowel metastasis of advanced melanoma 
Salven et al. (1997) have demonstrated that up-regulation of VEGF-A expression in metastatic melanoma is associated with an increase in the number of tumour-infiltrating inflammatory cells expressing VEGF-A.

FGF-2 regulates endothelial cell proliferation and angiogenesis by both autocrine and paracrine mechanisms. Since FGF-2 is devoid of the classic signal peptide for secretion, tumour cells release this factor by exocytosis from endoplasmic reticulum. Significant amounts of FGF-2 were found to be associated with extracellular matrix as well as with basement membrane of the newly formed blood vessels in human melanomas. Digestion of extracellular matrix by matrix metalloproteinases of melanoma or endothelial origin promotes release of matrix bound FGF-2, which, in turn, stimulates endothelial cell proliferation and vascular tube formation in melanomas. We and other authors (Salven et al., 1997) have demonstrated a significant correlation between melanoma progression, percentage of FGF-2-expressing tumour cells, and the number of mast cells which, in turn, secrete other angiogenic molecules, such as VEGF-A.

Another important stimulator of melanoma angiogenesis is PGF. PGF-1 and -2 are expressed by melanoma cells and are known to bind neuropilin- 1 and -2 receptors expressed on endothelial cells (Odorisio et al., 2006). In addition, PGF acts through binding VEGF-R1 inducing the mobilization and recruitment of VEGF-R1+ hematopoietic precursors from bone marrow and enhancing blood vessel maturation by acting on VEGF-R1-expressing smooth muscle cells/pericytes (Donnini et al., 1999). Moreover, PGF forms heterodimers with VEGF-A and enhances melanoma angiogenesis by activating VEGF-R2 on endothelial cells (Donnini et al., 1999; Luttun et al., 2004).

IL-8 expression was found to be very little in normal epidermis and benign melanocytic lesions. However, it is dramatically increased in the majority of cutaneous melanomas. Its serum levels in patients are significantly elevated compared to healthy individuals and correlate with advanced disease stage as well as with overall survival (Bar-Eli et al., 1999). Melanoma-derived IL-8 is able to induce endothelial cell migration, modulate vascular permeability, and enhance actin stress fiber formation. These activities resulted in enhanced angiogenesis, rapid tumour growth, and increased metastatic potential (Mahler et al., 2004; Melnikova \& Bar-Eli, 2006). Liu et al. (2005) have demonstrated that TGF-1 is able to enhance expression of IL-8 in human melanoma cells and promote angiogenesis in several mouse xenograft models.

Melanotransferrin, a member of the transferrin family, which is comprised of serum transferrin, lactoferrin and ovotransferrin, is highly expressed on melanoma cells compared to normal melanocytes. It exerts an angiogenic response quantitatively similar to that elicidated by FGF-2, and its angiogenic activity may depend on activation of endogenous VEGF. We have demonstrated that melanotransferrin contributes to angiogenesis during melanoma progression, and is likely associated with VEGF overexpression.

\section{Tumour microenvironment}

Neoplastic cells are influenced by their microenvironment and viceversa. The specific organ microenvironment determines the extent of cancer cell proliferation, angiogenesis, invasion and survival (Park et al., 2000; Liotta \& Kohn, 2001). These data indicate that a permissive stromal environment is important in supporting tumour progression in combination with genetic alterations. 
Tumour cells are surrounded by an infiltrate of inflammatory cells, namely lymphocytes, neutrophils, macrophages and mast cells, which communicate via a complex network of intercellular signalling pathways, mediated by surface adhesion molecules, cytokines and their receptors.

The inflammatory cell infiltrate, particularly macrophages, may contribute to tumour angiogenesis, and there are many reports of associations between macrophage infiltration, vascularity and prognosis. Tumour-associated macrophages accumulate in poorly vascularized hypoxic or necrotic areas (Leek et al., 1999) and respond to experimental hypoxia by increasing the release of VEGF and FGF-2 and a broad range of other factors, such as Tumour Necrosis Factor-alpha (TNF-a), urokinase and matrix metalloproteinases (Bingle et al., 2002). Moreover, activated macrophages synthesize and release inducible nitric oxide synthase, which increases blood flow and promotes angiogenesis (Jenkins et al., 1995). Lastly, the angiogenic factors secreted by macrophages stimulate mast cell migration (Gruber et al., 1995).

Chemokines also have a role: some CXC chemokines, such as IL-8 are pro-angiogenic (Bernardini et al., 2003). Chemokines may exert their regulatory activity on angiogenesis directly or as a consequence of leucocyte infiltration and/or the induction of growth factor expression. Malignant melanoma is also associated with a dramatic host response composed of mast cells at the tumour periphery.

Mast cells infiltrate hyperplasias, dysplasias and invasive fronts of carcinomas (but not the core of solid tumours), where they degranulate in close apposition to capillaries and epithelial basement membranes. Mast cells contain many angiogenic factors and a variety of cytokines, such as TGF- $\beta$, TNF- $\alpha$, IL-8, FGF-2, VEGF, implicated in normal, as well as tumour-associated neoangiogenesis.

Angiogenesis in human malignant melanoma, measured as microvessel counts, is highly correlated with both the percentage of tumour cells reactive to FGF-2 and mast cells counts (as total cell and tryptase-positive cell counts), and these parameters increase with tumour progression.

Two distinct types of human mast cells have been described based on the protease composition of their secretory granules: mast cells containing chymase, carboxypeptidase, cathepsin and tryptase and mast cells containing tryptase only. Tryptase, a protease unique to the mast cells secretory granules, acts as a mitogen for fibroblasts, smooth muscle cells, and epithelial cells (Brown et al., 1995; Cairns \& Walls, 1996).

Blair and colleagues (Blair et al., 1997) have shown that mast cell-released tryptase plays an important role in neovascularization. Tryptase induces the formation of capillary structures by either directly acting on endothelial cells or by facilitating the early stages of angiogenesis. In fact, tryptase activates latent matrix metalloproteinases and plasminogen activator (Stack \& Johnson, 1994), which degrade the extracellular matrix, a critical step in these stages (Mignatti \& Rifkin, 1993).

Mast cells are strikingly associated with angiogenesis in tumours, namely haemangioma, carcinomas, lymphoma and multiple myeloma where they are preferentially accumulated in the peripheral areas of the tumour, within the surrounding connective tissue, and rest near or around blood or lymphatic vessels. Mast cells are recruited and activated via several factors secreted by tumour cells: the c-kit receptor (Norrby \& Woolley, 1993), FGF-2, VEGF$\mathrm{A}$ and Platelet-Derived Endothelial Cell Growth Factor (PD-ECGF), which are operative at picomolar concentrations (Gruber et al., 1995). 
The fact that mast cells contribute to the induction of tumour angiogenesis stems from studies on mast cell-deficient mice, which display slow angiogenesis, and its restoration after local reconstitution of mast cells (Starkley et al., 1988; Toth et al., 2000). Moreover, in malignant breast lesions the number of mast cells with tryptase activity was significantly higher than in benign lesions (Kankunnen et al., 1997) and mast cells derived from human renal tumour tissues contained tryptase (Beil et al., 1998).

Tryptase-positive mast cells may contribute, at least partly, to the melanoma-associated angiogenesis. Furthermore, tumour-derived FGF-2 may have pleiotropic influences, first on tumour invasion, by elevating proteolytic enzymes, second on angiogenesis, by paracrine stimulation of endothelial cell growth, and third on recruitment and activation of mast cells, which express the FGF-2 receptor. Mast cells, in their turn, secrete FGF-2 stored in their secretory granules, which further stimulates endothelial cell growth and amplifies the FGF-2 paracrine stimulatory loop on angiogenesis.

\subsection{Integrin signalling and extracellular matrix enzymes}

Parallel with the angiogenic switch, an increasing number of tumour cells express the laminin receptor, which enables their adhesion to the vascular wall, favouring tumour cell extravasation and metastases. Our data indicate that melanoma cells express the 67-kDa laminin receptor in step with the progression from the nevocellular to the dysplastic nevi, and from the primary to the metastatic tumour. This expression enables melanoma cell adhesion to the vascular wall and together with the increased vascular network favours tumour cell extravasation and metastasis.

Overexpression of $a \mathrm{v} \beta 3, a \mathrm{v} \beta 5, a 2 \beta 1$, and $a 5 \beta 1$ integrins has been correlated with the transition from primary to metastatic melanoma (Bosserhoff, 2006). In turn, integrins overexpression stimulates matrix metalloproteinases -2 and -7 in melanoma cells, increasing their invasive potential (Kuphal et al., 2005).

Melanoma and tumour stromal cells express several matrix metalloproteinases, including matrix metalloproteinases -1, -2, -3, -7, -9, -14, -15, -16, as well as Tissue Inhibitors of Matrix Metalloproteinases such as TIMP-1,-2, and -3 (Hofmann et al., 2000a). Matrix metalloproteinases overexpression has been correlated with increased microvascular density, Bcl-2 overexpression, and low survival rate. The most extensively studied matrix metalloproteinases in melanomas are the isoforms -2 and -9 .

The expression and activation of both enzymes have been correlated to the invasive and metastatic phenotypes of the tumours (Hofmann et al., 2000b; Kerkela \& Saarialho-Kere, 2003; Nikkola et al., 2005; Cotignola et al., 2007; Schnaeker et al., 2004) in which they are constitutively expressed and highly associated with atypia and dedifferentiation into melanocytic lesions. Matrix metalloproteinase -2 expression was highly correlated with the metastatic spread and low survival rates (Hofmann et al., 2000a). Moreover, functional activity of matrix metalloproteinases is required for tumour progression. Overexpression of Membrane-Type- Matrix Metalloproteinase in melanoma cells induced activation of matrix metalloproteinase -2 which is crucial for extracellular matrix degradation. Matrix metalloproteinase -2 and Membrane-Type- Matrix Metalloproteinase + tumour cells were often restricted to the interface between the tumour invasive part and stroma (Durko et al., 1997; Hofmann et al., 2000b).

Expression of matrix metalloproteinases is not restricted to tumour cells but is also found abundantly in stromal cells indicating a major contribution of host-derived proteases to 
tumour progression (Wojtowicz-Praga et al., 1998). Also matrix metalloproteinase -1 expression is highly associated with melanoma progression (Nikkola et al., 2005). Matrix metalloproteinase -9 expression in melanoma cells was found exclusively during the horizontal growth phase but not during the vertical phase. This clearly suggests that expression of matrix metalloproteinase -9 is an early event in melanoma progression (Kerkela \& Saarialho-Kere, 2003).

Several studies using either cell lines or animal models have demonstrated that the balance between matrix metalloproteinases and their inhibitors finally determines melanoma progression (Hofmann et al., 2000b; Wojtowicz-Praga et al., 1998; Rudek et al., 2001; Jin et al., 2006; Wojtowicz-Praga et al., 1996; Bodey et al., 2001; Airola et al., 1999). Overexpression of TIMP-1, -2, and -3 significantly reduces melanoma tumour cell invasion, migration, growth and metastasis, and significantly reduces tumour neovascularization in several tumour models (Anand-Apte et al., 1996). Urokinase Plasminogen Activator and Its Receptor (uPA/uPAR) have been demonstrated to play a crucial role in several stages of melanoma progression including tumour cell migration, invasion, and metastasis. UPA secreted from melanoma cells is able to regulate endothelial cell functions including migration and the organization of endothelial cells into tube-like structures (Mueller, 1996; Delbaldo et al., 1994; Hearing et al., 1988).

The extracellular matrix enzymes and their inhibitors play also an important role in cancer dysregulated angiogenesis (Roy et al., 2009; Huang et al., 2009). These enzymes are the major degrading enzymes produced by angiogenic endothelial cells for migration through extracellular matrix during neovessel formation. Moreover, matrix metalloproteinases and TIMPs may act as regulators of signalling pathways through the cleavage of nonmatrix substrates, including cytokines, chemokines, and growth factors. In the last fifteen years, different extracellular matrix proteins and cleavage products have been identified. These molecules possess the ability to regulate vascular development, repair and function. Therefore, possible regulatory mechanisms in vascular biology controlled by different cleavage products of basement membrane proteins (e.g., endostatin and tumstatin, endorepellin), their activation by proteases and inhibitors, such as matrix metalloproteases, cathepsins, tissue inhibitors of matrix metalloproteinases and cystatin, have been reviewed in Suhr et al. (2009).

Integrin-Linked Kinase (ILK) is a highly conserved serine-threonine protein kinase involved in cell-extracellular matrix interactions, cytoskeletal organization and cell signalling. Overexpression of ILK in epithelial cells leads to anchorage-independent growth with increased cell cycle progression. ILK upregulation strongly correlates with melanoma progression, invasion and inversely correlates with 5-year survival of melanoma patients (Wani et al., 2011). However, the molecular mechanism by which ILK enhances melanoma progression is currently unknown. The proangiogenic molecule IL-6 is the downstream target of ILK in melanoma cells. Wani et al. (2011) have demonstrated that ILK overexpression increases IL-6, whereas silencing of ILK suppressed IL-6 expression at both messenger RNA and protein levels. ILK also alteres the activity and subcellular localization of Nuclear Factor-KappaB (NF-kB) subunit p65. ILK enhances the IL-6 gene transcription by promoting the binding of NF-kB p65 to IL-6 promoter. Moreover, ILK overexpression in melanoma cells enhances the tube-forming ability of endothelial cells in vitro and microvessel formation in vivo (Wani et al., 2011). 


\section{Hypoxia in melanoma progression}

Solid tumours, including melanomas, are characterized by areas of hypoxia/anoxia that result from an imbalance between oxygen supply and consumption in proliferating tumour cells. This imbalance is further exacerbated by a compromised tumour vasculature (Vaupel \& Mayer, 2007).

The presence of hypoxia within a tumour is an independent marker of a poor prognosis for patients with various cancer types including cutaneous melanomas. Because stringent hypoxia/anoxia $\left(<0.5 \% \mathrm{O}_{2}\right)$ is toxic for normal and tumour cells, it can promote tumour progression by selecting cells with mutations that allow them to survive in these extreme conditions. Furthermore, hypoxia activates signalling pathways that trigger neovascularization and that facilitate tumour cell invasion, migration, adhesion, and metastasis (Bedogni \& Broome Powell, 2009).

Metastasis is a complex multi-step process in which tumour cells have to acquire an invasive/migratory phenotype, enter the blood and lymphatic flow, survive anoikis and the immune response, and once localized to a distant site, survive in a likely hostile environment and proliferate. This process is relatively inefficient and only few cells within a tumour mass will have all the requirements that will allow them to successfully metastasize. Tumour hypoxia can influence most of the stages of metastasis (Bedogni \& Broome Powell, 2009).

Hypoxia has been involved in a Epithelial-Mesenchymal Transition-like process where tumour cells change from an epithelial non-motile phenotype to a mesenchymal migratory phenotype and gain the ability to invade other tissues. Epithelial-Mesenchymal Transition is accompanied by specific changes in gene expression, such as down-regulation of Ecadherin. Tumour hypoxia or loss of von Hippel-Lindau (VHL) which leads to HypoxiaInducible Factor (HIF) stabilization, down-regulates E-cadherin (Yang \& Wu, 2008). Furthermore, hypoxia through HIF-1, increases invasion by regulating genes, such as matrix metalloproteinase-2, that are involved in the degradation and remodelling of the extracellular matrix (Krishnamachary et al., 2003).

Via induction of pro-angiogenic factors such as VEGF, IL-8 and angiopoietin- 2, tumour hypoxia contributes to tumour angiogenesis providing cancer cells with access to blood vessels which is made easier by the leakiness of the tumour vasculature. HIF-1 can also increase resistance to anoikis by down-regulating the expression of $a 5$ integrin which mediates survival signals in the presence of extracellular matrix and apoptotic signals when cells lack adhesion to a substrate. Finally, by increasing the expression of lysyl oxidase, hypoxia/HIF-1 contributes to cancer metastasis in part by facilitating the recruitment of bone marrow derived cells to the metastatic niche, which prepares a receptive environment for cancer cells (Erler et al., 2009, 2006).

A direct role of hypoxia in advanced melanoma is slowly starting to emerge. HIF-1 has been shown to play a critical role in uveal melanoma progression by increasing the expression of a number of target genes involved in invasion. HIF-1 is regarded as one of the critical biomarkers that most accurately can predict uveal melanoma metastasis. Furthermore, a recent study by Qi et al. (2008), supports a role in melanomagenesis and metastasis of Siah2. Siah2, recently found to be regulated by the Serine/Threonine Protein Kinase Akt, is an inhibitor of Prolyl Hydroxylase Domain Protein function and therefore enhances hypoxia dependent HIF-1a stabilization by further inhibiting Prolyl Hydroxylase Domain Protein -1 and -3 in hypoxia. The authors found that blocking the axis Siah2-Spry2 leads to decreased 
HIF-1a stabilization, and results in a significant reduction of metastasis in a metastatic melanoma mouse model. This observation correlated with findings in human samples where reduced expression of the Siah2 substrates Prolyl Hydroxylase Domain Protein-3 and Spry2 and increased HIF-1 $a$ are characteristic of more advanced melanoma (Bedogni \& Broome Powell, 2009).

A role of HIF signalling in melanomagenesis is further supported by the work of Giatromanolaki et al. (2003). In this study, HIF-1 $a$ and HIF-2 $a$ were found to be expressed in 28 and $65 \%$ of melanoma samples respectively, and HIF-2a, together with VEGF and vascular density, was associated with poor overall disease survival.

In summary, these observations strongly support a role of hypoxia and HIF signalling in melanomagenesis and melanoma metastasis (Bedogni \& Broome Powell, 2009).

\section{Antiangiogenic therapies}

Different molecular targets of antiangiogenic molecules can be recognized, so various antiangiogenic agents are currently in clinical trials for melanoma.

Thalidomide was withdrawn from the market due to its teratogenecity, but in recent years its use has been focused on its anti-angiogenic properties (Frankset al., 2004; Kirchmair et al., 2007; Son et al., 2006). In fact, Thalidomide has been found to have antiangiogenic and antiinflammatory properties, and accordingly it has been used as a therapeutic agent in some malignant tumours including liver, renal cell, and breast carcinomas (Singhal \& Mehta, 2002).

We ourselves demonstrated that Thalidomide inhibits many genes which codify for angiogenic cytokines and their relative receptors in endothelial cells. Moreover, we have demonstrated that Thalidomide reduce the fundamental activity of activated endothelial cells (i.e. proliferation, migration, chemotaxis) as well as vessel formation in the Matrigel assay. It has been also proposed that the teratogenic property of Thalidomide involves in production of Reactive Oxygen Species (ROS), leading to subsequent DNA damage (Maniotis et al., 1999). When Thalidomide-induced ROS formation is inhibited, the anti-angiogenesis properties of Thalidomide will be reduced.

Thalidomide inhibits vasculogenic mimicry channel and mosaic vessels formation in melanoma through the regulation of vasculogenic factors, and it can induce necrosis of tumour cells, which may be related with the NF-kB signalling pathway (Zhang et al., 2008). In advanced melanoma Thalidomide has obtained some promising results when used as single agent. Pawlak and Legha (Pawlak \& Legha, 2004), published a study evaluating single-agent Thalidomide in metastatic malignant melanoma, showing no objective responses, but seven cases of stable disease.

Other single agent phase II studies (Reiriz et al., 2004; Eisen et al., 2000) demonstrated stable disease in a few patients, with $30 \%$ of the patients included in these trials having ocular melanoma. In another phase II study Thalidomide has shown limited activity in patients with metastatic melanoma against melanoma metastases in the Central Nervous System (CNS) (Lene et al., 2008). However, the minor effects founded on peripheral tumour manifestations, has led to the conclusion that Thalidomide might be part of the treatment strategy for these patients.

On the basis of these promising but non optimal results and since Thalidomide exhibits low oral bioavailability due to limitations in solubility, some experimental modification of oral preparation have been tested to improve the delivery of Thalidomide and its therapeutical 
activity (Kale et al., 2008). Its complexation with sulfobutyl ether-7 beta-cyclodextrin has demonstrated to increase stability, oral bioavailability, drug absorption, and distribution through solubilization of Thalidomide in experimental animals.

The safety and tolerability of adjuvant treatment with subcutaneous Granulocyte Macrophage Colony-Stimulating Factor (GM-CSF) administered in combination with escalating doses of Thalidomide in patients with surgically resected stage II (T4), III, or IV melanoma at high risk for recurrence has been also evaluated (Lutzky et al., 2009). This therapy has obtained promising results with a $42 \%$ overall survival at 2.6 years. However, the high incidence of life-threatening events, particularly thrombosis, that are unacceptable in the adjuvant setting, render the up-front antithrombotic prophylaxis necessary for further evaluation of this combination.

Many studies are also focused on the effects of Thalidomide on advanced melanoma in combination with Interferon alpha 2 b (Hutchins et al., 2007; Vaishampayan et al., 2007), Temozolomide (Quirt et al., 2007; Atkins et al., 2008), and Dacarbazine (Ott et al., 2009) with encouraging results. The combination of Pegylated Interferon and Thalidomide was evaluated in a phase II trial (Vaishampayan et al., 2007). Pegylated Interferon was administered at a dose of 0.5 microg/ $\mathrm{kg}$ subcutaneously weekly and Thalidomide $200 \mathrm{mg}$ orally daily. Dose escalation of Thalidomide to $300 \mathrm{mg}$ daily was feasible in some patients. This combination was well tolerated but failed to demonstrate clinical efficacy in pretreated metastatic melanoma. In fact, no objective responses were obtained, and only three patients achieved disease stabilization.

The addition of Thalidomide to Temozolomide with or without whole brain irradiation does not appear to provide a substantial advantage in the treatment of patients with CNS metastasis from melanoma but seems to add only toxicity. An initial study (Hwu et al., 2003) reported considerable activity (32\% response rate) for the Temozolomide and Thalidomide combination in the treatment of patients with systemic metastases from melanoma. This study combining Temozolomide in the prolonged administration schedule and Thalidomide at $200 \mathrm{mg} /$ day with dose escalation to $400 \mathrm{mg} /$ day produced 1 complete response and 11 partial responses in 38 patients with advanced melanoma and a median survival of 9.5 months. Evidence of response in CNS metastases was also reported in this setting. Subsequent results in a combined 53 evaluable patients in the Cytokine Working Group (CWG) and Cancer and Leukemia Group B (CALGB) studies are clearly disappointing (Quirt et al., 2007). Fatigue and an increased risk of thromboembolic events, without meaningfully increasing the modest CNS antitumour activity previously noted with the Temozolomide and whole brain irradiation combination (Margolin et al., 2002) or either Temozolomide (Agarwala et al., 2004) or whole brain irradiation alone (Fife et al., 2004). The conclusions of this study are consistent with the results of a CALGB trial using a similar regimen (Krown et al., 2006). This trial was stopped after 16 patients were enrolled because of excessive toxicity that included severe fatigue and sudden death in 1 patient and thromboembolic events (pulmonary embolism and deep vein thrombosis) in 4 patients. No tumour responses were observed in 14 evaluable patients.

Given the virtual lack of efficacy observed for the Temozolomide and Thalidomide combination against systemic disease in these 2 studies, the lack of significant CNS tumour response or major impact on overall survival is not surprising.

Similar results have been obtained when Thalidomide has been combined with Temozolomide alone in patients with stage IV malignant melanoma without active brain 
metastases (Joseph et al., 2010). In this phase II study patients received Thalidomide (200mg/d escalated to $400 \mathrm{mg} / \mathrm{d}$ for patients $<70$, or $100 \mathrm{mg} / \mathrm{d}$ escalated to $250 \mathrm{mg} / \mathrm{d}$ for patients $\geq 70$ ) plus Temozolomide $(75 \mathrm{mg} / \mathrm{m} 2 / \mathrm{d} \times 6$ weeks then 2 weeks rest). The progression free survival was $15 \%$ at 6 month and the overall survival was 35\% at 1 year. Enrolled patients obtained only partial response with a response rate of $13 \%$. Authors conclude that this combination of Thalidomide and Temozolomide does not appear to have a clinical benefit that exceeds Dacarbazine alone and they not recommend it further for phase III trials or for standard community use.

Similar results have been obtained when Thalidomide has been associated to Dacarbazine in the treatment of patients with advanced melanoma (Ott et al., 2009). Of the 13 patients evaluable for response of that enrolled in this phase II trial, 1 patient had a partial response, 3 patients had stable disease and 9 patients had progressive disease. No complete responses were achieved. 1 patient withdrew due to toxicity. Grade III/IV constipation, peripheral neuropathy, fatigue, edema and rash were attributed to Thalidomide addition. The authors conclude that Thalidomide dose escalation beyond $200 \mathrm{mg} /$ day was limited by unacceptable toxicity and this combination yielded activity insufficient to proceed with additional trials.

In the last years Lenalidomide, a less toxic analogue of Thalidomide, has been tested in vitro and in vivo. Lenalidomide has been showed good efficacy in hematologic and non hematologic cancer with a good toxicity profile (Zeldis et al., 2011). Promising preliminary results have been obtained in a study recruit 13 patients with stage IV malignant melanoma (Bartlett et al., 2004). Despite the fact that clinical response was not the primary end-point of the study and that the patients had not responded to prior therapy, clear evidence of drug activity in rapidly progressing malignant melanoma with one partial response and two minor responses of visceral disease have been obtained.

Subsequent studies (Glaspy et al., 2009; Eisen et al., 2010) have demonstrated that treatment with Lenalidomide $(25 \mathrm{mg} / \mathrm{d})$ has a manageable safety profile in patients with previously treated metastatic malignant melanoma. Although no benefit in tumour response, time to progression, or overall survival has been achieved in these patients, future trials for treatment of metastatic malignant melanoma with Lenalidomide should be conduct which focus its use in combination therapies (Lu et al., 2009).

On the basis of preclinical findings indicating that continuous low dose (metronomic) chemotherapy is thought to inhibit tumour angiogenesis, the evaluation of antiangiogenic potency of various chemotherapeutic drugs for metronomic chemotherapy, particularly Taxol, is ongoing for its efficacy (Drevs et al., 2004). In a pivotal study, 20 patients received paclitaxel $10 \mathrm{mg} / \mathrm{m}^{2}$ for 96 hours weekly as a continuous intravenous infusion and oral celecoxib $400 \mathrm{mg}$ twice daily. One patient achieved a partial response, and 3 of 20 patients $(15 \%)$ had stable disease for $>6$ months. The median time to progression was 57 days, and the median overall survival was 212 days. These findings support a role for metronomic therapy in patients with advanced melanoma. (Bhatt et al., 2010).

A newest approach to cancer therapy is to target the multicellular biological entity of the tumour microenvironment. This type of combination causes an inhospitable microenvironment for tumour cells and represent a great promise for clinical use. (Blansfield et al., 2008).

Semaxanib, a small molecule inhibitor of the VEGFR-2 tyrosine kinase, has shown encouraging results in patients with metastatic melanoma (Kuenen et al., 2003; Peterson, et al., 2004) in whom it has also been evaluated in combination with Thalidomide to assess the efficacy, tolerability, pharmacokinetic, and pharmacodynamic characteristics (Mita et al., 
2007). This last study has demonstrated that the combination Semaxanib-Thalidomide is feasible and has also demonstrated antitumour activity in patients with metastatic melanoma who had failed prior therapy. Twelve patients were enrolled in this study and received 44 courses of Semaxanib at the fixed dose of $145 \mathrm{mg} / \mathrm{m} 2$ intravenously twice-weekly in combination with Thalidomide, commencing at $200 \mathrm{mg}$ daily with intrapatient dose escalation as tolerated. The principal toxicities included deep venous thrombosis, headache, and lower extremity edema. Out of ten patients evaluable for response, one complete response lasting 20 months and one partial response lasting 12 months were observed. Additionally, four patients had stable disease lasting from 2 to 10 months. These results indicate that the combination of Semaxanib and Thalidomide is feasible and demonstrated anti-tumour activity in patients with metastatic melanoma who had failed prior therapy.

Another way to inhibit angiogenesis is the inhibition of matrix metalloproteinase activity. In the early 1990, matrix metalloproteinase inhibitors generated great enthusiasm among several research groups wishing to take them to clinical trials. Preclinical trials of matrix metalloproteinase inhibitors were very promising, showing minimum side effects compared to other drugs available at the time. Several current inhibitors, which have been tested in preclinical and clinical trials, are broad category matrix metalloproteinase inhibitors. Pharmacological inhibitors such as Prinomastat, Batimastat, and its analog Marimastat, which interfere with the catalytic site of the matrix metalloproteinases, were the first inhibitors studied in detail. Most of the inhibitors tested in clinical trials were not very promising due to the lack of positive outcomes and the appearance of substantial drug side effects, which were not observed in preclinical studies. Therefore, most of the inhibitor clinical trials were terminated following phase 3 clinical trials (Quirt et al., 2002; Pavlaki \& Zucker, 2003; Coussens et al., 2002).

Good therapeutic effects have been obtained in little studies with the combination of Bevacizumab (the anti-VEGF monoclonal antibody) and chemotherapy in advanced melanoma. Moreover, preclinical data strongly support the use of a combination of Bevacizumab and Erlotinib, a tyrosine kinase receptors inhibitor (Varker et al., 2007; Perez et al., 2009; Vásquez et al., 2009; Schicher et al., 2009).

PI-88, a potent inhibitor of heparanase, demonstrates an overall survival and time to progression similar to standard chemotherapy (Basche et al., 2006). In a phase II trial (Lewis et al., 2008) a total of 44 patients were enrolled with about $60 \%$ of them previously treated. The median time to progression and overall survival was 1.7 months and 9 months, respectively. One $(2.4 \%)$ patient achieved a partial response and six $(14.6 \%)$ had stable disease as best response. At the end of six cycles of treatment, three of the 41 evaluable patients had non-progressive disease. Treatment was generally well tolerated with serious bleeding occured in two patients and positive anti-platelet antibody test in three patients. One of these four patients experienced an associated thrombosis. These results indicate that in patients with advanced melanoma, PI-88 demonstrates an overall survival and time to progression similar to standard chemotherapy with evidence of activity that warrantee further investigation.

Preclinical data suggest that the ectopic expression of alphaIlb beta3 in melanoma cells can be exploited as a novel target of antibody therapy (Mitjans et al., 2000).

Although most of these study have obtained encouraging results, further evaluations of therapeutic strategies that target multiple angiogenesis pathways may be warranted in patients with advanced melanoma and other malignancies.

Finally, antiangiogenic therapy might have the unintended effect of promoting tumour metastasis by increasing vasculogenic mimicry as an alternative circulatory system (Qu et al., 2010). When the endothelium-dependent vessels are inhibited by the effective angiogenesis inhibitors, the hypoxia of tumour cells caused by antiangiogenesis may 
increase vasculogenic mimicry compensatively which can replace the job of endotheliumdependent vessels to maintain the tumour blood supply and provide a convenient route of tumour metastasis.

\section{Conclusion}

Tumour microenvironment plays a crucial role in the pathophysiology of human melanoma. It is involved in the crosstalk between melanoma cells and the microenvironment cells, which increases the survival, proliferation and migration of tumour cells themselves, and represents the substrate for angiogenesis which favours disease progression. Due to interaction with active microenvironment, neoplastic cells also acquire drug resistance giving less opportunity to therapy response.

Many research studies have tried to better understand the biological mechanisms and the genetic basis of all the interactions between tumour cells and the microenvironment cells. VEGF, FGF-2, IL-6, IL-8, macrophages, mast cells, and many others cells and molecules, play important roles in this process.

State the important role of angiogenesis in melanoma progression and diffusion, it represents a good target for biological therapies. Several molecules targeting the tumour microenvironment are actually evaluated in clinical trials and other compounds are in preclinical developing. However the initial results obtained with these compounds are promising, these approaches should be further developed.

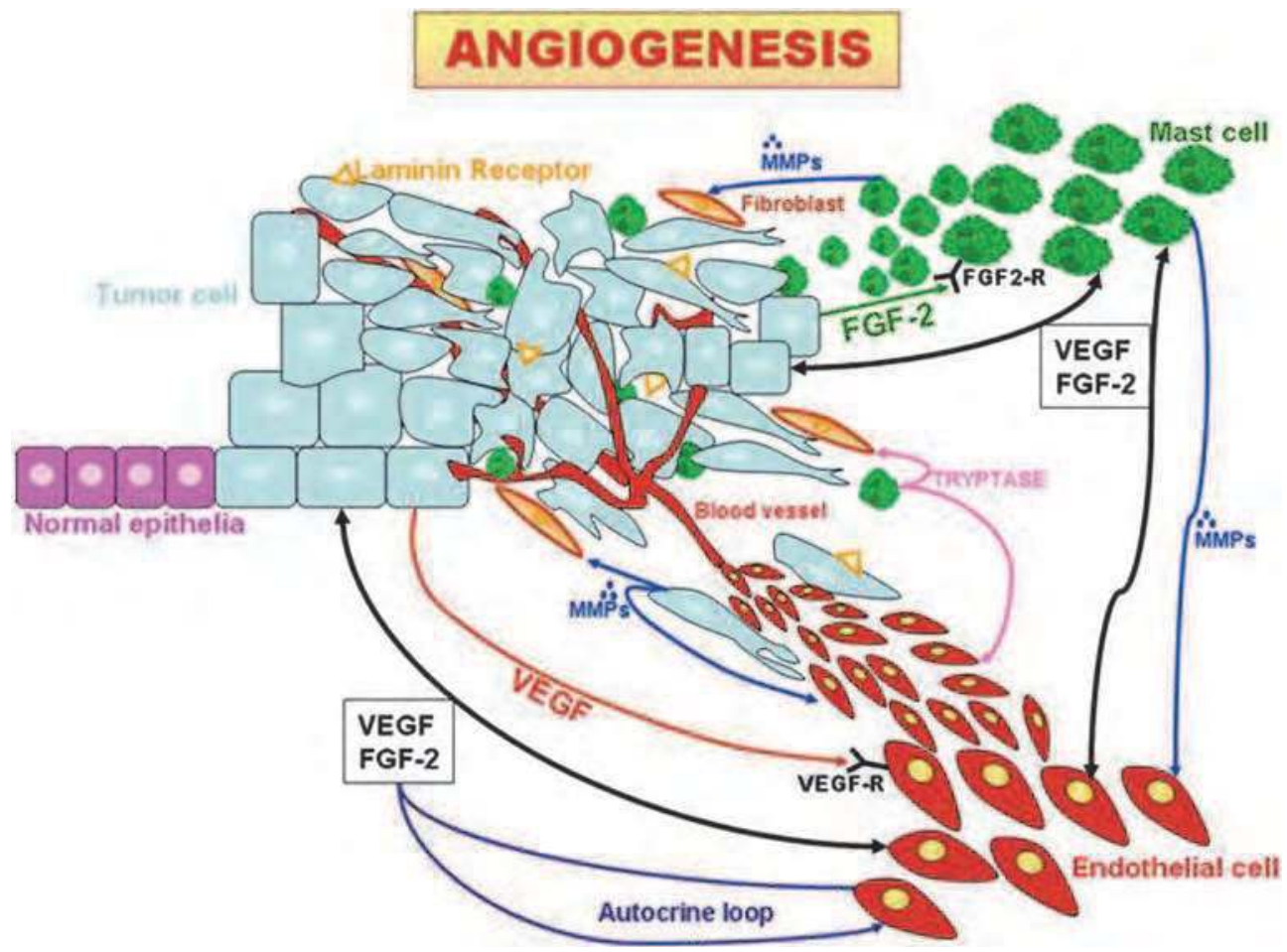

Fig. 3. Angiogenesis in human melanoma 


\section{Acknowledgments}

The Authors would like to thank Prof. Franco Dammacco, Prof. Domenico Ribatti, and Prof. Beatrice Nico for their technical support.

We would also like to thank to Prof. Cecilia Perillo for the English revision of the manuscript.

This work was supported by Associazione Italiana per la Ricerca sul Cancro (AIRC), Investigator Grant and Special Program Molecular Clinical Oncology 5 per mille n. 9965, Milan, Italy.

\section{References}

Agarwala, S.S., Kirkwood, J.M., Gore, M., Dreno, B., Thatcher, N., Czarnetski, B., Atkins, M., Buzaid, A., Skarlos, D., \& Rankin, E.M. (2004). Temozolomide for the treatment of brain metastases associated with metastatic melanoma: a phase II study. J ClinOncol., Vol. 22, No., pp. 2101-2107

Airola, K., Karonen, T., Vaalamo, M., Lehti, K., Lohi, J., Kariniemi, A.L., Keski-Oja, J., \& Saarialho-Kere, U.K. (1999). Expression of collagenases-1 and -3 and their inhibitors TIMP-1 and -3 correlates with the level of invasion in malignant melanomas. British Journal of Cancer, Vol.80, No.5-6, pp. 733-743

Anand-Apte, B., Bao, L., Smith, R., Iwata, K., Olsen, B.R., Zetter, B., \& Apte, S.S. (1996). A review of tissue inhibitor of metalloproteinases-3 (TIMP-3) and experimental analysis of its effect on primary tumour growth. Biochemistry and Cell Biology, Vol. 74, No.6, pp. 853-862

Atkins, M.B., Sosman, J.A., Agarwala, S., Logan, T., Clark, J.I., Ernstoff, M.S., Lawson, D., Dutcher, J.P., Weiss, G., Curti, B., \& Margolin, K.A. (2008). Temozolomide, Thalidomide, and whole brain radiation therapy for patients with brain metastasis from metastatic melanoma: a phase II cytokine working group study. Cancer, Vol. 113, No. 8, pp. 2139-2145

Balch, C.M., Soong, S.J., Gershenwald, J.E., Thompson, J.F., Reintgen, D.S., Cascinelli, N., Urist, M., McMasters, K.M., Ross, M.I., Kirkwood, J.M., Atkins, M.B., Thompson, J.A., Coit, D.G., Byrd, D., Desmond, R., Zhang, Y., Liu, P.Y., Lyman, G.H., \& Morabito, A. (2001). Prognostic factors analysis of 17,600 melanoma patients: validation of the American Joint Committee on Cancer melanoma staging system. J Clin Oncol., (Aug 15 2001), Vol.19, No.16, pp. 3622-34

Balch, C.M., Gershenwald, J.E., Soong, S.J., Thompson, J.F., Atkins, M.B., Byrd, D.R., Buzaid, A.C., Cochran, A.J., Coit, D.G., Ding, S., Eggermont, A.M., Flaherty, K.T., Gimotty, P.A., Kirkwood, J.M., McMasters, K.M., Mihm, M.C. Jr, Morton, D.L., Ross, M.I., Sober, A.J., \& Sondak, V.K. (2009). Final version of 2009 AJCC melanoma staging and classification. J Clin Oncol., (Dec 20 2009), Vol.27, No.36, pp. 6199-206

Bar-Eli, M. (1999). Role of interleukin-8 in tumour growth and metastasis of human melanoma. Pathobiology, Vol. 67, No. 1, pp. 12-18

Bartlett, J.B., Michael, A., Clarke, I.A., Dredge, K., Nicholson, S., Kristeleit, H., Polychronis, A., Pandha, H., Muller, G.W., Stirling, D.I., Zeldis, J., \& Dalgleish, A.G. (2004). Phase I study to determine the safety, tolerability and immunostimulatory activity 
of Thalidomide analogue CC-5013 in patients with metastatic malignant melanoma and other advanced cancers. British Journal of Cancer, No. 90, pp. 955-961

Basche, M., Gustafson, D.L., Holden, S.N., O'Bryant, C.L., Gore, L., Witta, S., Schultz, M.K., Morrow, M., Levin, A., Creese, B.R., Kangas, M., Roberts, K., Nguyen, T., Davis, K., Addison, R.S., Moore, J.C., \& Eckhardt, S.G. (2006). A phase I biological and pharmacologic study of the heparanase inhibitor PI-88 in patients with advanced solid tumours, Clinical Cancer Research, Vol. 12, No. 18, pp. 5471-5480

Bedogni, B., \& Broome Powell M. (2009). Hypoxia, melanocytes and melanoma - survival and tumour development in the permissive microenvironment of the skin. Pigment Cell Melanoma Res, 22(2):166-74

Beil, W.J., Fureder, W., Wiener, H., Grosschmidt, K., Maier, U., Schedle, A., Bankl, H.C., Lechner, K., \& Valent, P. (1998). Phenotypic and functional characterization of mast cells derived from renal tumour tissues. Exp. Hematol., No. 26, pp. 158-169

Bernardini, G., Ribatti, D., Spinetti, G., Morbidelli, L., Ziche, M., Santoni, A., Capogrossi, M.C., \& Napolitano, M. (2003). Analysis of the role chemokines in angiogenesis. J Immunol Methods, No. 273, pp. 83-101

Bhatt, R.S., Merchan, J., Parker, R., HK, Wu., Zhang, L., Seery, V., Heymach, J.V., Atkins, M.B., McDermott, D., \& Sukhatme, V.P. (2010). A phase 2 pilot trial of low-dose, continuous infusion, or "metronomic" paclitaxel and oral celecoxib in patients with metastatic melanoma. Cancer, Vol. 116, No. 7, pp. 1751-6

Bingle, L., Brown, N.J., \& Lewis, C.E. The role of tumour associated macrophages in tumour progression: implications for new anticancer therapies. (2002). J Pathol., No. 196, pp. 254-65

Blair, R.J., Meng, H., Marchese, M.J., Ren, S., Schwartz, L.B., Tonnesen, M.G., \& Gruber, B.L. (1997). Human mast cells stimulate vascular tube formation. Tryptase is a novel, potent angiogenic factor. J. Clin. Invest., No. 99, pp. 2691-2700

Blansfield, J.A., Caragacianu, D., Alexander, H.R. 3rd, Tangrea, M.A., Morita, S.Y., Lorang, D., Schafer, P., Muller, G., Stirling, D., Royal, R.E., \& Libutti, S.K. (2008). Combining agents that target the tumour microenvironment improves the efficacy of anticancer therapy. Clin Cancer Res, Vol. 14, No. 1, pp. 270-80

Bodey, B., Gr"oger, A.M., Siegel, S.E., \& Kaiser, H.E. (2001). Invasion and metastasis: the expression and significance of matrix metalloproteinases in carcinomas of the lung. In Vivo, Vol. 15, No. 2, pp. 175-180

Bosserhoff, A. K. (2006). Novel biomarkers inmalignant melanoma. Clinica Chimica Acta, Vol. 367 , No. 1-2, pp. 28-35

Breslow, A. (1970) Thickness, cross-sectional areas and depth of invasion in the prognosis of cutaneous melanoma. Annals of Surgery, Vol. 172, No. 5, pp. 902-908

Brown, J.K., Jones, C.A., Tyler, C.L., Ruoss, S.J., Hartmann, T., \& Caughey, G.H. (1995). Tryptase-induced mitogenesis in airway smooth muscle cells. Chest, No. 107, pp. 95S-96S

Cairns, J.A. \& Walls, A.F. (1996). Mast cell tryptase is a mitogen for epithelial cells: stimulation of IL-8 production and intercellular adhesion molecule-1 expression. J. Immunol., No. 157, pp. 275-283 
Clark, J.C., Moon, J., Hutchins, L.F., Sosman, J.A., Kast, W.M., Da Silva, D.M., Liu, P.Y., Thompson, J.A., Flaherty, L.E., \& Sondak, V.K. (2010). Phase II Trial of Combination Thalidomide plus Temozolomide in Patients with Metastatic Malignant Melanoma: Southwest Oncology Group S0508. Cancer, Vol. 116, No. 2, pp. 424-431

Cotignola, J., Reva, B., Mitra, N., Ishill, N., Chuai, S., Patel, A., Shah, S., Vanderbeek, G., Coit, D., Busam, K., Halpern, A., Houghton, A., Sander, C., Berwick, M., \& Orlow, I. (2007). Matrix metalloproteinase-9 (MMP-9) polymorphisms in patients with cutaneous malignant melanoma. BMC Medical Genetics, Vol. 8, Article 10

Coussens, L.M., Fingleton, B., \& Matrisian, L. M. (2002). Matrix metalloproteinase inhibitors and cancer: trials and tribulations. Science, Vol. 295, No. 5564, pp. 2387-2392

Delbaldo, C., Masouye, I., Saurat, J.-H., Vassalli, J.-D., \& Sappino, A.-P. (1994). Plasminogen activation in melanocytic neoplasia. Cancer Research, Vol. 54, No. 16, pp. 4547-4552

Dome, B., Hendrix, M.J., Paku, S., Tóvári, J., \& Tímár, J. (2007). Alternative vascularisation mechanisms in cancer: pathology and therapeutic implications. Am J Pathol., No. 170, pp. 1-15

Donnini, S., Machein, M. R., Plate, K. H., \& Weich, H. A. (1999). Expression and localization of placenta growth factor and P1GF receptors in human meningiomas. Journal of Pathology, Vol. 189, No. 1, pp. 66-71

Drevs, J., Fakler, J., Eisele, S., Medinger, M., Bing, G., Esser, N., Marmé, D., \& Unger, C. (2004). Antiangiogenic potency of various chemotherapeutic drugs for metronomic chemotherapy. Anticancer Research, Vol. 24, No. 3A, pp. 1759-1763

Durko, M., Navab, R., Shibata, H. R., \& Brodt, P. (1997). Suppression of basement membrane type IV collagen degradation and cell invasion in human melanoma cells expressing an antisense RNA for MMP-1. Biochimica et Biophysica Acta, Vol. 1356, No. 3, pp. 271-280

Eisen, T., Boshoff, C., Mak, I., Sapunar, F., Vaughan, M.M., Pyle, L., Johnston, S.R., Ahern, R., Smith, I.E., \& Gore, M.E. (2000). Continuous low dose Thalidomide: A phase II study in advanced melanoma, renal cell, ovarian and breast cancer. Br J Cancer., Vol. 82, pp. 812-7

Eisen, T., Trefzer, U., Hamilton, A., Hersey, P., Millward, M., Knight, R.D., Jungnelius, J.U., \& Glaspy. (2010). J. Results of a Multicenter, Randomized, Double-Blind Phase 2/3 Study of Lenalidomide in the Treatment of Pretreated Relapsed or Refractory Metastatic Malignant Melanoma. Cancer, No. 116, pp. 146-54

Erhard, H., Rietveld, F. J. R., van Altena, M. C., Bröcker, E.B., Ruiter, D.J., \& de Waal , R.M. (1997). Transition of horizontal to vertical growth phase melanoma is accompanied by induction of vascular endothelial growth factor expression and angiogenesis, Melanoma Research, Vol. 7, No. 2, pp. S19-S26

Erler, J.T., Bennewith, K.L., Nicolau, M., Dornhofer, N., Kong, C., Le, Q.T., Chi, J.T., Jeffrey, S.S., \& Giaccia, A.J. (2006). Lysyl oxidase is essential for hypoxia-induced metastasis. Nature, No. 440, pp. 1222-1226

Erler, J.T., Bennewith, K.L., Cox, T.R., Lang, G., Bird, D., Koong, A., Le, Q.T., \& Giaccia AJ. (2009). Hypoxia induced lysyl oxidase is a critical mediator of bone marrow cell recruitment to form the premetastatic niche. Cancer Cell., No. 15, pp. 35-44 
Fife, K.M., Colman, M.H., Stevens, G.N., Firth, I.C., Moon, D., Shannon, K.F., Harman, R., Petersen-Schaefer, K., Zacest, A.C., Besser, M., Milton, G.W., McCarthy, W.H., \& Thompson, J.F. (2004). Determinants of outcome in melanoma patients with cerebral metastases. J Clin Oncol., Vol. 22, pp. 1293-1300

Folkman, J., Browder, T., \& Palmblad, J. (2001). Angiogenesis research: guidelines for translation to clinical application. Thromb Haemost., No. 86, pp. 23-33

Franks, M.E., Macpherson, G.R., \& Figg, W.D. (2004). Thalidomide. Lancet, No. 363, pp. 1802-1811;

Garbe, C., Terheyden, P., Keilholz, U., Kölbl, O., \& Hauschild, A. (2008). Treatment of Melanoma. Dtsch Arztebl Int., Vol. 105, No. 49, pp. 845-51

Giatromanolaki, A., Sivridis, E., Kouskoukis, C., Gatter, K.C., Harris, A.L., \& Koukourakis, M.I. (2003). Hypoxia-inducible factors 1alpha and 2alpha are related to vascular endothelial growth factor expression and a poorer prognosis in nodular malignant melanomas of the skin. Melanoma Res., No. 13, pp. 493-501

Glaspy, J., Atkins, M.B., Richards, J.M., Agarwala, S.S., O’Day, S., Knight, R.D., Jungnelius, J.U., \& Bedikian, A.Y. (2009). Results of a Multicenter, Randomized, Double-Blind, Dose-Evaluating Phase 2/3 Study of Lenalidomide in the Treatment of Metastatic Malignant Melanoma. Cancer, No. 115, pp. 5228-36

Gruber, B.L., Marchase, M.J., \& Kaw, R. (1995). Angiogenic factors stimulate mast cell migration. Blood, No. 86, pp. 2488-93

Hearing, V. J., Law, L. W., Corti, A., Appella, E., \& Blasi, F. (1988). Modulation of metastatic potential by cell surface urokinase of murine melanoma cells. Cancer Research, Vol. 48, No. 5, pp.1270-1278

Heasley, D.D., Toda, S., \& Mihm Jr., M.C. (1996). Pathology of malignant melanoma. Surgical Clinics of North America, Vol. 76, No. 6, pp. 1223-1255

Hofmann, U.B., Westphal, J.R., Van Muijen, G.N.P., \& Ruiter, D.J. (2000a). Matrix metalloproteinases in human melanoma. Journal of Investigative Dermatology, Vol. 115, No. 3, pp. 337-344

Hofmann, U.B., Westphal, J.R., Zendman, A.J.W., Becker, J.C., Ruiter, D.J., \& Van Muijen, G.N.P. (2000b). Expression and activation of matrix metalloproteinase-2 (MMP-2) and its colocalization with membrane-type I matrix metalloproteinase (MTI-MMP) correlate with melanoma progression. Journal of Pathology, Vol. 191, No. 3, pp. 245256

Huang, S.C., Sheu, B.C., Chang, W.C., Cheng, C.Y., Wang, P.H., \& Lin, S. (2009). Extracellular matrix proteases - cytokine regulation role in cancer and pregnancy. Frontiers in Bioscience, Vol. 14, pp. 1571-1588

Hubler, Jr W., \& Wolf, Jr J. (1976). Melanoma. Tumour angiogenesis and human neoplasia. Cancer, No. 38, pp. 187-192

Hutchins, L.F., Moon, J., Clark, J.I., Thompson, J.A., Lange, M.K., Flaherty, L.E., \& Sondak, V.K. (2007). Evaluation of interferon alpha-2B and Thalidomide in patients with disseminated malignant melanoma, phase 2, SWOG 0026. Cancer, Vol. 110, No. 10, pp. 2269-2275

Hwu, W.J., Krown, S.E., Menell, J.H., Panageas, K.S., Merrell, J., Lamb, L.A., Williams, L.J., Quinn, C.J., Foster, T., Chapman, P.B., Livingston, P.O., Wolchok, J.D., \& 
Houghton, A.N. (2003). Phase II study of Temozolomide plus Thalidomide for the treatment of metastatic melanoma. J Clin Oncol., Vol. 21, pp. 3351-3356

Iruela-Arispe, M.L., \& Dvorak, H.F. (1997). Angiogenesis: a dynamic balance of stimulators and inhibitors. Thromb Haemost., No. 78, pp. 672-677

Jenkins, D.C., Charles, I.G., Thompson, L.L., Moss, D.W., Holmes, L.S., Baylis, S.A., Rhodes, P., Westmore, K., Emson, P.C., \& Moncada, S. (1995). Role of nitric oxide in tumour growth. Proc Natl Acad Sci USA, No. 92, pp. 4392-6

Jin, X., Yagi, M., Akiyama, N., Hirosaki, T., Higashi, S., Lin, C.Y., Dickson, R.B., Kitamura, H., \& Miyazaki, K. (2006). Matriptase activates stromelysin (MMP-3) and promotes tumour growth and angiogenesis. Cancer Science, Vol. 97, No. 12, pp. 1327-1334

Kale, R., Tayade, P., Saraf, M., \& Juvekar, A. (2008). Molecular encapsulation of Thalidomide with sulfobutyl ether-7 beta-cyclodextrin for immediate release property: enhanced in vivo antitumour and antiangiogenesis efficacy in mice. Drug Dev Ind Pharm, Vol. 34, No. 2, pp. 149-56

Kankunnen, J.P., Harvima, I.T., \& Naukkarinen, A. (1997). Quantitative analysis of tryptase and chimase containing mast cells in benign and malignant breast lesions. Int. J. Cancer, No. 72, pp. 385-388

Kerkela, E., \& Saarialho-Kere, U. (2003). Matrix metalloproteinases in tumour progression: focus on basal and squamous cell skin cancer. Experimental Dermatology, Vol. 12, No. 2, pp. 109-125

Kirchmair, R., Tietz, A.B., Panagiotou, E., Walter, D.H., Silver, M., Yoon, Y.S., Schratzberger, P., Weber, A., Kusano, K., Weinberg, D.H., Ropper, A.H., Isner, J.M., \& Losordo, D.W. (2007). Therapeutic angiogenesis inhibits or rescues chemotherapy-induced peripheral neuropathy: taxol- and Thalidomide-induced injury of vasa nervorum is ameliorated by VEGF. Mol Ther, Vol. 15, No. 1, pp. 69-75

Krishnamachary, B., Berg-Dixon, S., Kelly, B., Agani, F., Feldser, D., Ferreira, G., Iyer, N., LaRusch, J., Pak, B., Taghavi, P., \& Semenza, G.L. (2003). Regulation of colon carcinoma cell invasion by hypoxia-inducible factor 1. Cancer Res., 63:1138-1143

Krown, S.E., Niedzwiecki, D., Hwu, W.J., Hodgson, L., Houghton, A.N., \& Haluska, F.G. (2006). Phase II study of Temozolomide and Thalidomide in patients with metastatic melanoma in the brain: high rate of thromboembolic events (CALGB 500102). Cancer., Vol. 107, pp. 1883-1890

Kuenen, B.C., Tabernero, J., Baselga, J., Cavalli, F., Pfanner, E., Conte, P.F., Seeber, S., Madhusudan, S., Deplanque, G., Huisman, H., Scigalla, P., Hoekman, K., \& Harris, A.L. (2003). Efficacy and toxicity of the angiogenesis inhibitor SU5416 as a single agent in patients with advanced renal cell carcinoma, melanoma, and soft tissue sarcoma. Clinical Cancer Research, Vol. 9, No. 5, pp. 1648-1655

Kuphal, S., Bauer, R., \& Bosserhoff, A.K. (2005). Integrin signalling in malignant melanoma. Cancer and Metastasis Reviews, Vol.24, No. 2, pp. 195-222

Leek, R.D., Lander, R.J., Harris, A.L., \& Lewis, C.E. (1999). Necrosis correlates with high vascular density and focal macrophages infiltration in invasive carcinoma of the breast. Br J Cancer, No. 79, pp. 991-5 
Lene, W., Vestermark, Larsen, S., Lindeløv, B., \& Bastholt, L. (2008). A phase II study of Thalidomide in patients with brain metastases from malignant melanoma. Acta Oncologica, Vol. 47, pp. 1526-1530

Lewis, K.D., Robinson, W.A., Millward, M.J., Powell, A., Price, T.J., Thomson, D.B., Walpole, E.T., Haydon, A.M., Creese, B.R., Roberts, K.L., Zalcberg, J.R., \& Gonzalez, R. (2008). A phase II study of the heparanase inhibitor PI-88 in patients with advanced melanoma. Invest New Drugs, Vol. 26, No. 1, pp. 89-94

Liotta, L., \& Kohn, E.C. (2001). The microenvironment of the tumour-host interface. Nature, No. 411 , pp. 375-9

Liu, G., Zhang, F., Lee, J., \& Dong, Z. (2005). Selective induction of interleukin-8 expression in metastatic melanoma cells by transforming growth factor- $\beta 1$. Cytokine, Vol. 31, No. 3, pp. 241-249

Lu L., Payvandi, F., Wu, L., Zhang, L.H., Hariri, R.J., Man, H.W., Chen, R.S., Muller, G.W., Hughes, C.C., Stirling, D.I., Schafer, P.H., \& Bartlett, J.B. (2009). The anti-cancer drug Lenalidomide inhibits angiogenesis and metastasis via multiple inhibitory effects on endothelial cell function in normoxic and hypoxic conditions. Microvascular Research, Vol. 77, No. 2, pp. 78-86

Luttun, A., Autiero, M., Tjwa, M., \& Carmeliet, P. (2004). Genetic dissection of tumour angiogenesis: are PlGF and VEGFR-1 novel anti-cancer targets? Biochimica et Biophysica Acta, Vol. 1654, No. 1, pp. 79-94

Lutzky, J., Weber, R., Nunez, Y., Gillett, M., \& Spitler, L. (2009). A phase 1 study of granulocyte macrophage colony-stimulating factor (sargramostim) and escalating doses of Thalidomide in patients with high-risk malignant melanoma. Journal of Immunotherapy, Vol. 32, No. 1, pp. 79-85

Mahler, D.A., Huang, S., Tabrizi, M., \& Bell, G.M. (2004). Efficacy and safety of a monoclonal antibody recognizing interleukin-8 in COPD: a pilot study. Chest, Vol. 126, No. 3, pp. 926-934

Maniotis, A.J., Folberg, R., Hess, A., Seftor, E.A., Gardner, L.M., Pe'er, J., Trent, J.M., Meltzer, P.S., \& Hendrix, M.J. (1999). Vascular channel formation by human melanoma cells in vivo and vitro: vasculogenic mimicry. Am J Pathol., Vol. 155, pp. 739-752

Marcoval, J., Moreno, A., Graells, J., Vidal, A., Escribà, J.M., Garcia-Ramírez, M., \& Fabra, A. (1997). Angiogenesis and malignant melanoma. Angiogenesis is related to the development of vertical (tumourigenic) growth phase. Journal of Cutaneous Pathology, Vol. 24, No. 4, pp. 212-218

Margolin, K., Atkins, B., Thompson, A., Ernstoff, S., Weber, J., Flaherty, L., Clark, I., Weiss, G., Sosman, J., II Smith, W., Dutcher, P., Gollob, J., Longmate, J., \& Johnson, D. (2002). Temozolomide and whole brain irradiation in melanoma metastatic to the brain: a phase II trial of the Cytokine Working Group. J Cancer Res Clin Oncol., Vol. 128, pp. 214-218

Melnikova, V.O., \& Bar-Eli, M. (2006). Bioimmunotherapy for melanoma using fully human antibodies targeting MCAM/MUC18 and IL-8. Pigment Cell Research, Vol. 19, No. 5, pp. 395-405

Mignatti, P., \& Rifkin, D.B. (1993). Biology and biochemistry of proteinases in tumour invasion. Physiol. Rev., No. 73, pp. 161-195 
Mihm, Jr M., Clark, Jr W., \& Reed, R. (1975). The clinical diagnosis of malignant melanoma. Semin. Oncol., No. 2, pp. 105-118

Mita M.M., Rowinsky, E.K., Forero, L., Eckhart, S.G., Izbicka, E., Weiss, G.R., Beeram, M., Mita, A.C., de Bono, J.S., Tolcher, A.W., Hammond, L.A., Simmons, P., Berg, K., Takimoto, C., \& Patnaik, A. (2007). A phase II, pharmacokinetic, and biologic study of semaxanib and Thalidomide in patients with metastatic melanoma. Cancer Chemotherapy and Pharmacology, Vol. 59, no. 2, pp. 165-174

Mitjans, F., Meyer, T., Fittschen, C., Goodman, S., Jonczyk, A., Marshall, J.F., Reyes, G., \& Piulats, J. (2000). In vivo therapy of malignant melanoma by means of antagonists of av integrins. International Journal of Cancer, Vol. 87, No. 5, pp. 716-723

Mueller, M.B. (1996). Different roles for plasminogen activators and metalloproteinases inmelanomametastasis. Current Topics in Microbiology and Immunology, Vol. 213, pp. $65-80$

Nikkola, J., Vihinen, P., Vuoristo, M.-S., Kellokumpu-Lehtinen, P., Kahari, V.M., \& Pyrh"onen, S. (2005). High serum levels of matrix metalloproteinase-9 and matrix metalloproteinase-1 are associated with rapid progression in patients with metastatic melanoma. Clinical Cancer Research, Vol. 11, No. 14, pp. 5158-5166

Norrby, K., \& Woolley, D. (1993). Role of mast cells in mitogenesis and angiogenesis in normal tissue and tumour tissue. Adv. Biosci., No. 89, pp. 71-115

Odorisio, T., Cianfarani, F., Failla, C.M., \& Zambruno, G. (2006). The placenta growth factor in skin angiogenesis. Journal of Dermatological Science, Vol. 41, No. 1, pp. 11-19

Ott, P.A., Chang, J.L., Oratz, R., Jones, A., Farrell, K., Muggia, F., \& Pavlick, A.C. (2009). Phase II trial of Dacarbazine and Thalidomide for the treatment of metastatic melanoma. Chemotherapy, Vol. 55, No. 4, pp. 221-227

Park, C.C., Bissell, M.J., \& Barcellos-Hoff, M.H. (2000). The influence of the microenvironment on the malignant phenotype. Mol Med Today, No. 6, pp. 324-9

Pavlaki, M., \& Zucker, S. (2003). Matrix metalloproteinase inhibitors (MMPIs): the beginning of phase I or the termination of phase III clinical trials. Cancer and Metastasis Reviews, Vol. 22, No. 2-3, pp. 177-203

Pawlak, W.Z., \& Legha, S.S. (2004). Phase II study of Thalidomide in patients with metastatic melanoma. Melanoma Res, Vol. 14, pp. 57-62

Perez, D.G., Suman, V.J., Fitch, T.R., Amatruda, T. 3rd, Morton, R.F., Jilani, S.Z., Constantinou, C.L., Egner, J.R., Kottschade, L.A., \& Markovic, S.N. (2009). Phase 2 trial of carboplatin, weekly paclitaxel, and biweekly bevacizumab in patients with unresectable stage IV melanoma: a North Central Cancer Treatment Group study, N047A. Cancer, Vol. 115, No. 1, pp. 119-127

Peterson, A.C., Swiger,S., Stadler, S.M., Medved, M., Karczmar, G., \& Gajewski, T.F.(2004). Phase II study of the Flk-1 tyrosine kinase inhibitor SU5416 in advanced melanoma. Clinical Cancer Research, Vol. 10, No. 12, part 1, pp. 4048-4054

Qi, J., Nakayama, K., Gaitonde, S., Goydos, J.S., Krajewski, S., Eroshkin, A., Bar-Sagi, D., Bowtell, D., \& Ronai, Z. (2008). The ubiquitin ligase Siah2 regulates tumourigenesis and metastasis by HIF-dependent and -independent pathways. Proc Natl Acad Sci USA, No. 105, pp. 16713-16718 
Qu, B., Guo, L., Ma, J., \& Lv, Y. (2010). Antiangiogenesis therapy might have the unintended effect of promoting tumour metastasis by increasing an alternative circulatory system. Medical Hypotheses, Vol. 74, No. 2, pp. 360-361

Quirt, I., Bodurth, A., Lohmann, R., Rusthoven, J., Belanger, K., Young, V., Wainman, N., Stewar, W., Eisenhauer, E.; National Cancer Institute of Canada Clinical Trials Group. (2002). Phase II study of marimastat (BB-2516) in malignant melanoma: a clinical and tumour biopsy study of the National Cancer Institute of Canada Clinical Trials Group. Investigational New Drugs, Vol. 20, No. 4, pp. 431-437

Quirt, I., Verma, S., Petrella, T., Bak, K., \& Charette,M. (2007). Temozolomide for the treatment of metastatic melanoma: a systematic review. Oncologist, Vol. 12, No. 9, pp. 1114-1123

Reiriz, A.B., Richter, M.F., Fernandes, S., Cancela, A.I., Costa, T.D., DiLeone, L.P., \& Schwartsmann, G. (2004). Phase II study of Thalidomide in patients with metastatic malignant melanoma. Melanoma Res, Vol. 14, pp. 527-31

Risau, W., Sariola, H., Zerwes, H.G., Sasse, J., Ekblom, P., Kemler, R., \& Doetschman, T. (1988). Vasculogenesis and angiogenesis in embryonic stem-cell-derived embryoid bodies. Development, No. 102, pp. 471-478

Roy, R., Yang, J., \& Moses, M.A. (2009). Matrix metalloproteinases as novel biomarkers and potential therapeutic targets in human cancer. Journal of Clinical Oncology, Vol. 27, No. 31, pp. 5287-5297

Rudek, M.A., Figg, W.D., Dyer, V., Dahut, W., Turner, M.L., Steinberg, S.M., Liewehr, D.J., Kohler, D.R., Pluda, J.M., \& Reed, E. (2001). Phase I clinical trial of oral COL-3, a matrix metalloproteinase inhibitor, in patients with refractory metastatic cancer. Journal of Clinical Oncology, Vol. 19, No. 2, pp. 584-592

Salven, P., Heikkil"a, P., \& Joensuu, H. (1997). Enhanced expression of vascular endothelial growth factor in metastatic melanoma. British Journal of Cancer, Vol. 76, No. 7, pp. 930-934

Schicher, N., Paulitschke, V., Swoboda, A., Kunstfeld, R., Loewe, R., Pilarski, P., Pehamberger, H., Hoeller, C. (2009). Erlotinib and bevacizumab have synergistic activity against melanoma. Clinical Cancer Research, Vol. 15, No. 10, pp. 3495-3502

Schnaeker, E.-M., Ossig, R., Ludwig, T., Dreier, R., Oberleithner, H., Wilhelmi, M., \& Schneider, S.W. (2004). Microtubule-dependent matrix metalloproteinase-2/matrix metalloproteinase-9 exocytosis: prerequisite in human melanoma cell invasion. Cancer Research, Vol. 64, No. 24, pp. 8924-8931

Singhal, S., \& Mehta, J. (2002). Thalidomide in cancer. Biomedicine and Pharmacotherapy, Vol. 56, No. 1, pp. 4-12

Son, M.J., Kim, J.S., Kim, M.H., Song, H.S., Kim, J.T., Kim, H., Shin, T., Jeon, H.J., Lee, D.S., Park, S.Y., Kim, Y.J., Kim, J.H., \& Nam, D.H. (2006). Combination treatment with Temozolomide and Thalidomide inhibits tumour growth and angiogenesis in an orthotopic glioma model. Int J Oncol., Vol. 28, No. 1, pp. 53-59

Srivastava, A., Laidler, P., Davies, R.P., Horgan, K., \& Hughes, L.E. (1988). The prognostic significance of tumour vascularity in Dermatology Research and Practice 5 intermediate-thickness $(0.76-4.0 \mathrm{~mm}$ thick) skin melanoma. A quantitative histologic study. American Journal of Pathology, Vol. 133, No. 2, pp. 419-423 
Srivastava, A., Hughes, L.E., Woodcock, J.P., \& Laidler, P. (1989). Vascularity in cutaneous melanoma detected by Doppler sonography and histology: correlation with tumour behaviour. British Journal of Cancer, Vol. 59, No. 1, pp. 89-91

Stack, M.S. \& Johnson, D.A. (1994). Human mast cell tryptase activates single-chain urinarytype plasminogen activator (pro-urokinase). J. Biol. Chem., No. 269, pp. 9416-9419

Starkey, J.R., Crowle, P.K., \& Taubenberg, S. (1988). Mast cell-deficient W/Wv mice exhibit a decreased rate of tumour angiogenesis. Int. J. Cancer, No. 42, pp. 48-52

Stasi, R., \& Amadori, S. (2002). The role of angiogenesis in hematologic Malignancies. J of Hematotherapy \& stem cell research, No. 11, pp. 49-68

Streit, M., \& Detmar, M. (2003). Angiogenesis, lymphangiogenesis, and melanoma metastasis. Oncogene, No. 22, pp. 3172-3179

Suhr, F., Brixius, K., \& Bloch, W. (2009). Angiogenic and vascular modulation by extracellular matrix cleavage products. Current Pharmaceutical Design, Vol. 15, No. 4, pp. 389-410

Toth, T., Toth-Jakatics, R., Jimi, S., Takebayashi, S., \& Kawamoto, N. (2000). Cutaneous malignant melanoma: correlation between neovascularization and peritumour accumulation of mast cells overexpressing vascular endothelial growth factor. Hum. Pathol, No. 31, pp. 955-960

Vaishampayan, U.N., Heilbrun, L.K., Marsack,C., Smith, D.W., \& Flaherty, L.E. (2007). Phase II trial of pegylated interferon and Thalidomide in malignant metastatic melanoma. Anti-Cancer Drugs, Vol. 18, No. 10, pp. 1221-1226

Varker, K.A., Biber, J.E., Kefauver, C., Jensen, R., Lehman, A., Young, D., Wu, H., Lesinski, G.B., Kendra, K., Chen, H.X., Walker, M.J., \& Carson, W.E. 3rd. (2007). A randomized phase 2 trial of bevacizumab with or without daily low-dose interferon alfa-2b in metastatic malignant melanoma. Annals of Surgical Oncology, Vol. 14, No. 8, pp. 2367-2376

Vásquez, L.M., Somani, S., Altomare, F., \& Simpson, E.R., (2009). Intracameral bevacizumab in the treatment of neovascular glaucoma and exudative retinal detachment after brachytherapy in choroidal melanoma. Canadian Journal of Ophthalmology, Vol. 44, No. 1, pp. 106-107

Vaupel, P., \& Mayer, A. (2007). Hypoxia in cancer: significance and impact on clinical outcome. Cancer Metastasis Rev., No. 26, pp. 225-239.

Wani, A.A., Jafarnejad, S.M., Zhou, J., \& Li, G. (2011). Integrin-linked kinase regulates melanoma angiogenesis by activating NF-kB/interleukin-6 signalling pathway. Oncogene, PMID 21278793

Warren, B.A., \& Shubik, P. (1966). The growth of the blood supply to melanoma transplants in the hamster cheek pouch. Lab. Invest., No. 15, pp. 464-478

Wojtowicz-Praga, S., Low, J., Marshall, J., Ness, E., Dickson, R., Barter, J., Sale, M., McCann, P., Moore, J., Cole, A., \& Hawkins, M.J. (1996). Phase I trial of a novel matrix metalloproteinase inhibitor batimastat (BB-94) in patients with advanced cancer. Investigational New Drugs, Vol. 14, No. 2, pp. 193-202

Wojtowicz-Praga, S., Torri, J., Johnson, M., Steen, V., Marshall, J., Ness, E., Dickson, R., Sale, M., Rasmussen, H.S., Chiodo, T.A., \& Hawkins, M.J. (1998). Phase I trial of Marimastat, a novel matrix metalloproteinase inhibitor, administered orally to 
patients with advanced lung cancer. Journal of Clinical Oncology, Vol. 16, No. 6, pp. 2150-2156

Yang, M.H., \& Wu, K.J. (2008). TWIST activation by hypoxia inducible factor-1 (HIF-1): implications in metastasis and development. Cell Cycle, No. 7, pp. 2090-2096

Zeldis, J.B., Knight, R., Hussein, M., Chopra, R., Muller, G., \& Ann, N.Y. (2011) A review of the history, properties, and use of the immunomodulatory compound Lenalidomide. Acad Sci., Vol. 1222, No. 1, pp. 76-82

Zhang, S., Li, M., Gu, Y., Liu, Z., Xu, S., Cui, Y., \& Sun, B. (2008). Thalidomide influences growth and vasculogenic mimicry channel formation in melanoma. Journal of Experimental and Clinical Cancer Research, Vol. 27, No. 1, article 60 


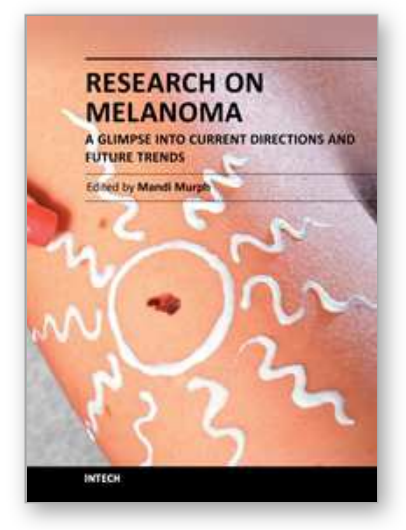

\author{
Research on Melanoma - A Glimpse into Current Directions and \\ Future Trends \\ Edited by Prof. Mandi Murph
}

ISBN 978-953-307-293-7

Hard cover, 414 pages

Publisher InTech

Published online 12, September, 2011

Published in print edition September, 2011

The book Research on Melanoma: A Glimpse into Current Directions and Future Trends, is divided into sections to represent the most cutting-edge topics in melanoma from around the world. The emerging epigenetics of disease, novel therapeutics under development and the molecular signaling aberrations are explained in detail. Since there are a number of areas in which unknowns exist surrounding the complex development of melanoma and its response to therapy, this book illuminates and comprehensively discusses such aspects. It is relevant for teaching the novice researcher who wants to initiate projects in melanoma and the more senior researcher seeking to polish their existing knowledge in this area. Many chapters include visuals and illustrations designed to easily guide the reader through the ideas presented.

\title{
How to reference
}

In order to correctly reference this scholarly work, feel free to copy and paste the following:

Roberto Ria, Antonia Reale and Angelo Vacca (2011). Role of Angiogenesis and Microenvironment in Melanoma Progression, Research on Melanoma - A Glimpse into Current Directions and Future Trends, Prof. Mandi Murph (Ed.), ISBN: 978-953-307-293-7, InTech, Available from:

http://www.intechopen.com/books/research-on-melanoma-a-glimpse-into-current-directions-and-futuretrends/role-of-angiogenesis-and-microenvironment-in-melanoma-progression

\section{INTECH}

open science | open minds

\author{
InTech Europe \\ University Campus STeP Ri \\ Slavka Krautzeka 83/A \\ 51000 Rijeka, Croatia \\ Phone: +385 (51) 770447 \\ Fax: +385 (51) 686166 \\ www.intechopen.com
}

\author{
InTech China \\ Unit 405, Office Block, Hotel Equatorial Shanghai \\ No.65, Yan An Road (West), Shanghai, 200040, China \\ 中国上海市延安西路65号上海国际贵都大饭店办公楼 405 单元 \\ Phone: +86-21-62489820 \\ Fax: +86-21-62489821
}


(C) 2011 The Author(s). Licensee IntechOpen. This chapter is distributed under the terms of the Creative Commons Attribution-NonCommercialShareAlike-3.0 License, which permits use, distribution and reproduction for non-commercial purposes, provided the original is properly cited and derivative works building on this content are distributed under the same license. 